\title{
The sanctuary of Delphi in Heliodorus'Aethiopica: Between material culture and intertextuality
}

\author{
Cecilia Nobili \\ Università degli Studi di Milano
}

\section{Delphi and the nostalgic evocation of Classical Greece}

Divine and religious elements are a prominent feature of Greek novels and sacred spaces often play an important narrative function. ${ }^{1}$ In Chariton's novel, Callirhoe meets Chaereas on her way to the temple of Aphrodite in Syracuse $(1,1,6)$ and her second husband in the goddess's temple in Miletus $(3,9,1)$. Similarly, in the Ephesian Tales the protagonists meet in the temple of Aphrodite at Ephesus and the action develops from here (1,1,5-6). In Heliodorus' Aethiopica a long and detailed section is devoted to the description of the sanctuary of Delphi $(2,26-3,6)$, where the main characters of the plot meet and whence they depart before embarking on all the fantastic adventures recounted in the novel. ${ }^{2}$ In all cases, the description of sacred spaces becomes an exercise in ekphrasis, because Heliodorus carefully depicts statues, temples and sacred objects, balancing real elements with idealized or 'psychologized' features. ${ }^{3}$

The importance attributed to Delphi as the centre of the Greek world in the Aethiopica is particularly meaningful. As several critics have investigated - particularly Tim Whitmarsh - this romance reflects a problematic conflict between Greekness and non-Greekness, ${ }^{4}$ which leads the protagonists - and the author

\footnotetext{
${ }^{1}$ Edsall 2002; Zeitlin 2008; Dowden 2010. Several studies have investigated the role of space in the development of the plots of Greek novels (see Paschalis-Frangoulidis 2002; De Temmerman and Morgan in De Jong 2012). However, with few exceptions (e.g. Tagliabue 2013), none of them specifically examines cultic places.

2 On the novel's multiple starting points and on Delphi's effective centrality, see Hilton 1996.

${ }^{3}$ On ekphrasis see n. 21 below.

${ }^{4}$ The problem has been investigated by Whitmarsh 1998 and 2011, 108-135, who underlines the contrast between the general Hellenism of the novel and Heliodorus' Syrian origin,
} 
himself - to search for an identity that finds its starting point and culmination in the omphalos of the world. ${ }^{5}$ The novel exhibits an abundance of geographical core centres that apparently defies any attempt to establish its identity: the narrative begins in Aegypt and Kalasiris is Aegyptian; Heliodorus, as he himself declares in the final sphragis, is a Phoenician from Emesa ${ }^{6}{ }^{6}$ and Charikleia has Aethiopian origins, so that the whole plot is focused on her desperate attempt to return to her homeland. Nonetheless, in this multiplicity of geographical points of reference, Delphi, as the quintessence of Greekness, represents the ideal starting point of the plot, where the centripetal forces of the narrative converge. This notion finds a perfect counterpart in John Morgan's interpretation of the Aethiopica as 'an endorsement, assertion and extension of Hellenism', best illustrated by the intertextual references to Classical Greek authors embedded throughout the novel. As Morgan and other scholars have now clarified, the model for the romance is the Odyssey, from both a thematic and structural point of view. ${ }^{7}$ As Whitmarsh notes, 'Charicleia and Theagenes, then, can be read as the Odyssey that Homer would have written had he lived his days on the fertile banks of the Nile'.

The abundance of allusions to Classical Greek authors is in line with the dramatic date of the novel - the fourth century BC - and the Atticistic prose that characterizes it. Several internal elements are now recognized by scholars as pointing to this dramatic date: Aristippus' role as a member of the 'upper council' in Athens, for instance, and the mode of Demainete's suicide. But we also find specific connections in the Delphic section. ${ }^{9}$ As Diodorus Siculus $(16,26,6)$ recounts, in 355/354 BC a Pythian priestess was seized and raped by a Thessalian

and, more generally, the problematic multiple cultural identities presented by the author; see also Morgan 2014, who highlights the Greekness and Hellenocentrism of the novel.

${ }^{5}$ Cf. Whitmarsh 2011, 115: 'In another sense, however, Charicleia and Theagenes remains a centre-periphery text: from the Ethiopians' vantage, this is precisely a story about expatriation into an unfamiliar foreign space, and subsequent home-coming. Charicleia is the girl, says her father Hydaspes, "whom [the gods] exiled from her home land to the ultimate limits (perata ... eskhata) of the earth" (10.16.6). This reorientation is all the more striking when we consider that it is Delphi - for Greeks, the "navel" (omphalos) or "hearth" of the world - to which Hydaspes is referring'.

${ }^{6}$ On Phoenician elements in the novel, see Bowie 1998; Whitmarsh 2011, 109-110, who also reconstructs the original Phoenician name of Heliodorus as Abdshamash, 'Servant of Sun'; Quinn 2017, 149-152.

${ }^{7}$ Morgan 2014, 267-268. See also Bowie 1998; Whitmarsh 1998, 97-99; Elemer 2008, $412-$ 417; Telò 2011; Tagliabue 2015.

${ }^{8}$ Whitmarsh 2011, 114.

${ }^{9}$ See Lateiner 1997; Morgan 1996, 434-435, suggests the fifth century BC as a date and underlines Heliodorus' dependence on literary sources for his historical reconstruction: 'The learning is derived from literature and deployed for literary purposes, to encourage an imaginative belief in the reality of the fiction'. 
called Echecrates; as a result, the people of Delphi ruled that only women older than 50 years of age could give oracles at the shrine, although they were still required to dress as virgins. ${ }^{10}$ Charikleia's abduction in the Aethiopica echoes this event, and it also results in a revision of the rules governing the Pythian games: the priestess of Artemis should no longer present the prize for those running in the hoplite race $(4,21,1)$, since it was Charikleia's public appearance in this role that led Theagenes to plan her abduction.

The Classical setting is consistent with the general ideology of the novel, whose date of composition is now generally accepted to be the mid-fourth century AD. ${ }^{11}$ The quest for Greekness that appears to be one of the hallmarks of the novel results in a nostalgic triumph of paganism over oriental religions, which presents several points of contact with the religious programme promoted by Emperor Julian and his attempt to restore pagan religious worship - with special emphasis on heroic cults - in opposition to Christianity. ${ }^{12}$ The role of Apollo in the Delphic section is also exemplary: his will - made known through the prophecies of the Pythia - sets the plot in motion and justifies the protagonists' actions. Heliodorus - as the name itself reveals - considers himself a 'descendent of the Sun', the identification between Apollo and the Sun being common in the Imperial age. ${ }^{13}$ The cult of Helios was also at the core of Julian's philosophy, as expressed in his Hymn to King Helios, which presents several analogies with Heliodorus'

${ }^{10}$ See Lateiner 1997.

${ }^{11}$ See Bowersock 1994, 149-160; Morgan 1996, 417-421; Whitmarsh 2011, 109-112; Mecella 2014; Ross 2015. The main arguments for dating the romance to the fourth century AD are: the fictitious siege of Syene in Book 9 which seems to evoke the siege of Nisibis by the Parthians in AD 350, as described in two panegyrics to Constantius by the future emperor Julian (Orations I and III); a mention of Heliodorus as bishop of Trikka in AD 384 by the Church Historian Sokrates; the coherence between the novel's ideology and Julian's Hellenizing reform.

12 On the relationship between Heliodorus and Julian's philosophy, see Gregory 1983; Jones 2010, 88-90; Hilton 1996, 2012a and b; Morgan 2014, 266-267; Mecella 2014. On Julian's attempt to revive hero cults and blood sacrifices, see Amm. Marc. 22,12,6 and Bradbury 1995. On Heliodorus' gods and religion, see Bargheer 1999; Edsall 2002.

${ }^{13}$ See Plut. De defect. oracul. 433d-e; De E ap. Delph. 393d; Bargheer 1999, 93-118. This identification and the more general identification of Theagenes with Apollo/Helios and of Charikleia with Artemis/Selene/Isis is a key element in Merkelbach's theory of the novel as a mystery text (Merkelbach 1962, 234-298; see previously Kerényi 1927). Nonetheless, Kerenyi-Merkelbach's theory is now generally dismissed (see Zeitlin 2008; Dowden 2005 and 2010; Beck 1996, p. 145: 'The Aethiopica, then, may fairly be called a religious novel, a product of the solar piety of late antiquity intended to edify within that context. What it is not is a solar mystery text, for the very good reason that there were no solar mysteries, in the sense of an organized cult to which the work might be assigned as hieros logos'). Heliodorus' careful interest in a reliable reconstruction of Classical Greece through intertextual references also weighs against this thesis. 
thought. ${ }^{14}$ The ideology of Greekness typical of fourth-century authors sympathetic with Julian's programme thus characterizes the whole novel and the choice of Delphi as a starting point must be understood in the light of this. Heliodorus' careful description of the sanctuary and its ceremonies is, once again, a way of advertising his Greekness, and his deep knowledge of Greek literary sources and of the most important Classical sites. ${ }^{15}$

In the second book of the novel, the Egyptian priest of Isis Kalasiris recounts that he ran away from Egypt in order to escape the seductive influence of the courtesan Rhodopis ${ }^{16}$ and found refuge in Delphi $(2,26,1)$. Here he meets the young protagonists of the story, Theagenes, a noble Thessalian boy who came to visit the sanctuary and attend the Pythian festival, and Charikleia, a girl of extraordinary beauty, abandoned at birth by her mother, an Aethiopian queen, and adopted by Charikles, the priest of Apollo at Delphi. The girl grew up in the sanctuary and became priestess of Artemis until the day she met Theagenes and fell in love with him. At this point Kalasiris takes the kids to Africa in order to discover Charikleia's true origins and allow them to fulfill their love dream.

The description of the sanctuary is detailed and generally evokes the material aspect of the site in the Imperial age. However, its truthfulness has been debated: Pouilloux defends the verisimilitude of the overview, whereas Rougemont accuses Heliodorus of scarce adherence to reality. ${ }^{17}$ Although different elements may be invoked in support of both arguments, Heliodorus' reconstruction of the site must be regarded as accurate: the inconsistencies derive from an adaptation of reality to the author's narrative and ideological strategies, and by the conflation of Classical sources and Imperial reality. The reconstruction of Delphi mainly depends on literary sources, but we cannot exclude that a Hellenized pagan author like Heliodorus visited this monument from a glorious past as a pilgrim, as Kalasiris does and as was common in Late Antiquity. ${ }^{18}$ This means that several aspects of the narrative are mediated through the eyes of the authors who inspired Heliodorus, primarily Philostratus and Plutarch. As a result, visual elements are repeatedly combined with intertextual connections, and Classical authors' suggestions are adapted to the context of Imperial ideology and reality.

\footnotetext{
14 See Smith 1995, 139-162; Hilton 2012b; Mecella 2014.

${ }^{15}$ On Heliodorus' general pursuit of realism, see Morgan 1982.

${ }^{16}$ On the figure of Rhodopis in the Aethiopica, see Nobili 2016a.

17 Pouilloux 1983 and 1984; Rougemont 1992.

${ }^{18}$ E.g. Dio Chrysostom (8; 9) vividly describes the Isthmian festivals in the first century AD. On pagan pilgrimages to Greek sanctuaries in Imperial times, see Dillon 1997; Galli 2005; Rutherford 2013, 47-50; on Delphi specifically, see Weir 2004.
} 
The Delphic section of the Aethiopica opens with Kalasiris' assumption that Delphi is a holy place, 'a retreat, where philosophers could work far from the madding crowd' $(2,26,1)$.

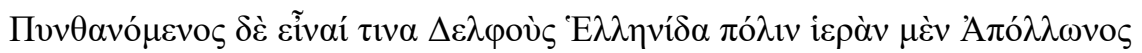

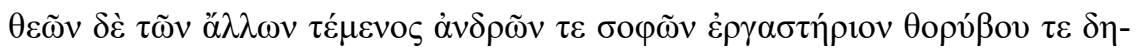

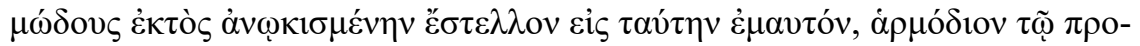

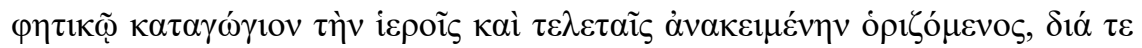

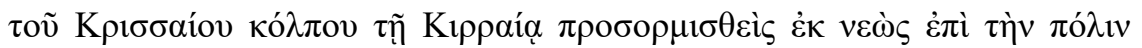
$\dot{\alpha} v \varepsilon \dot{\varepsilon} \theta \varepsilon \circ v$.

I learned that in Greece there was a city called Delphi, sacred to Apollo but a holy place for the other gods too, a retreat where philosophers could walk far from the madding crowd. Here I made my way, for it seemed to me that a town devoted to holy rites and ceremonies was a place of refuge well suited to a member of the priestly caste. I sailed along the Krisaian Gulf and came to anchor at Kirrhaia, where I left my ship and hastened up to the city. (transl. J. Morgan, as the following ones)

This idea of Delphi as a meeting point for philosophers and wise men that recurs in the novel $(2,26,1$ and 2,27) clearly derives from Plutarch. In De Pythiae oraculis, De defectu oraculorum and the De E apud Delphos, he makes the sanctuary with its monuments and treasures - a setting for erudite conversations between his wise protagonists (philosophers, grammarians and priests). ${ }^{19}$ The opening of De defectu oraculorum, for example, describes the convergence at Delphi, the navel of world, of two ö $v \delta \rho \varepsilon \varsigma$ i $\varepsilon \rho o i ̀$, the grammarian Demetrios and the Spartan philosopher Cleombrotos. ${ }^{20}$

In Heliodorus' novel Kalasiris disembarks at Chrysa, modern Itea, and the first sight of the sanctuary from the sea is astonishing: it appears like a fortress, surrounded and hidden by the rocky slopes of Parnassus, which encompasses it on all sides $(2,26,2)$.

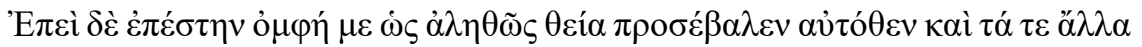

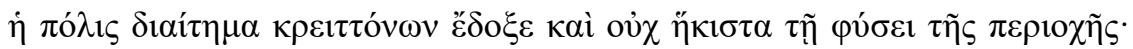

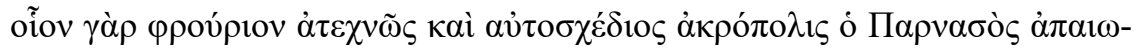

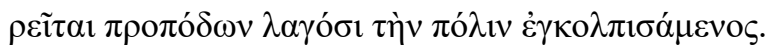

${ }^{19}$ This image is also reflected by the dedications of Sophists and philosophers: see Pouilloux 1967; Weir 2004, 111-116.

${ }^{20}$ Plut. De Defect. Orac. 410a. 
As I entered the town, the place's own oracular voice sang in my ears in tones that truly were heaven-sent. The city seemed like an abode fit for the lords of heaven, especially as regards the nature of its surroundings: Parnassos towers above the city exactly like a fortress or a natural citadel, enfolding the town in the fond embrace of the foothills.

Such a description certainly reflects a well-established literary tradition which emphasizes the overwhelming presence of Parnassus in the sanctuary of Delphi and which dates back to the Homeric Hymn to Apollo (282-284). Here the mountain is described as 'snowy Parnassus, a west-facing spur with the cliff hanging over it and a hollow, rugged glen extending below', and the Cretan mariners that Apollo engages as his first priests follow the same path as Kalasiris to ascend the mountain and reach the site (515-522). Strabo $(9,3,3,418)$ underlines the same aspects, and records his first impression of Delphi as 'a rocky place, theatre-like'. Nonetheless, Heliodorus' description is physically and materially accurate and reflects the actual view of the site that an ancient traveller disembarking at Chrysa would have gotten. The sanctuary was not visible from the sea, as the mountain encircled it, but it gradually appeared to pilgrims' eyes as a sort of revelation while they ascended the mountain.

This description of the sanctuary, as recounted by Kalasiris, is an interesting example of ekphrasis, since it expresses the point of view of a first-person narrator who moves slowly through space and time and, using a vivid language, emphasizes the personal impressions made by certain visual elements. As recent studies have now clarified, ekphrasis is something different from a mere 'description', because it involves the poet's sense-perception and his way of seeing and interpreting objects. ${ }^{21}$ As Goldhill states, ekphrasis represents 'not merely a work of art, but also the poet as seeing subject', ${ }^{22}$ and Elsner adds: 'ekphrasis is as much a venture into descriptive narrative as into description per se. Its aim is above all about creating an emotional effect in an audience's imagination and literally bringing the object described before the eyes of the listener or reader'. ${ }^{23}$ Descriptions of this kind, which involve the viewer's sensibility and aim to produce psychologizing effects on readers are disseminated throughout the Aethiopica: the Delphic section, with its grand procession filled with visual impressions, is one of the best examples of ekphrasis in Imperial prose. ${ }^{24}$

\footnotetext{
${ }^{21}$ Among the many contributions devoted to ekphrasis, see Bartsch 1989; Goldhill 1994 and 2007; Elsner 2002; Whitmarsh 2002; Squire 2009; Webb 2009 (181-185 for Heliodorus).

${ }^{22}$ Goldhill 1994, 205.

${ }^{23}$ Elsner 2002, 1.

${ }^{24}$ See Bartsch 1989, 120-122; Hardie 1998; Whitmarsh 2002; Webb 2009, 184-185. See also Tagliabue 2015 on the opening scene $(1,1-2,4)$.
} 
Upon his first arrival in Delphi, Kalasiris not only describes the monuments he admires by drawing on the literary tradition that preceded him, but also underlines the emotions they generate both through his own eyes and through those of any other imaginary spectator. Kalasiris himself is aware that reality and the imagination come together in his mind to recreate an idealized vision of the holy place: the boundaries between $\dot{\alpha} \lambda \hat{\eta} \theta \varepsilon 1 \alpha$ and $\delta$ ó $\xi \alpha$ become blurred, because - as Whitmarsh states - 'ekphrastic mimesis is a form of deceptive illusionism, invoking a fake, surrogate reality'. ${ }^{25}$ Furthermore, Kalasiris' description is interesting because it represents the non-Greek point of view of an Egyptian priest of Isis, who interprets the quintessentially Greek ideal of Delphi with the aid of his most beloved Classical sources; in doing so, he mirrors the voice of Heliodorus himself, who looks at Classical Greece from his Phoenician point of view.

As Kalasiris enters the town, he admires the squares, the fountains and the streets, and then proceeds to the temple, after taking a ritual bath in the Kastalia fountain $(2,26,4)$.

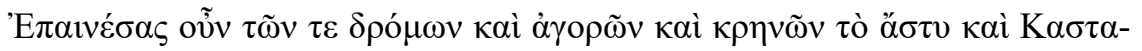

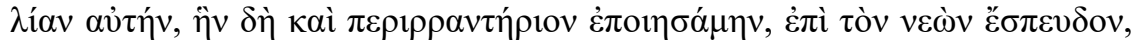

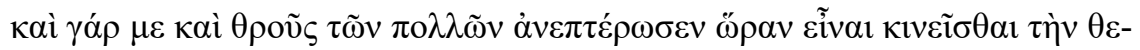

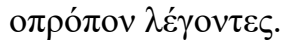

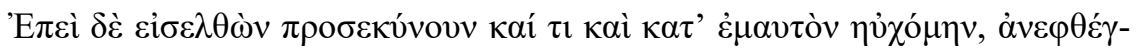

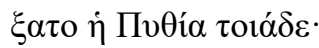

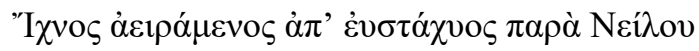

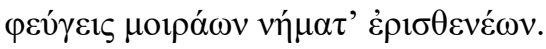

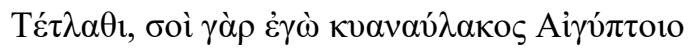

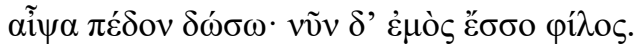

After admiring the town with its streets, squares, and fountains and visiting the famous spring of Kastalia, with whose waters I performed the ritual of ablution, I hastened to the temple in a state of high excitement, for the crowd was abuzz with the rumor that it was time for the prophetess to awake. I entered the temple, and as I knelt in private prayer, the Pythian priestess broke into speech.

From Nile's corn-rich banks your path has led

As you flee from far-reaching Fate's spun thread.

Fear not. The hour is near when I shall lead you home

To black-soiled Egypt. For now, friend, welcome!

${ }^{25}$ Whitmarsh 2002, 112. 
The description gives a clear idea of the wealth and high degree of monumentalization of the old town that was closely integrated within the sanctuary, lying as it did between the temenos of Apollo, the lower area of the gymnasium and the Marmaria terrace. The mention of the fountain bears witness to the abundance of water on the site, due to the presence of several springs flowing from the mountain. ${ }^{26}$ The most important was the Kastalia spring, monumentalized in the seventh century $\mathrm{BC}$ and then again in the first century $\mathrm{BC} .{ }^{27}$ The allusion to the agorai certainly reflects the liveliness of ancient Delphi, bustling with pilgrims from all over the Greek world, who would reside in the city for several weeks, awaiting the oracles' response. As recent research has revealed, no proper hostel existed in Delphi, so the squares' colonnades probably served as a makeshift dormitory for most visitors. ${ }^{28}$ The remains of a Roman agora have been excavated just before the southern entrance of the sanctuary, which with its huge columns may well give us an idea of Kalasiris' first impressions upon approaching the temple.

After the ritual bath, Kalasiris is finally permitted to enter the temenos, and he does so exactly as the Pythia is shaking on her tripod. When the Pythia sees him, she utters an extraordinary oracle before the crowd, prophesying that Kalasiris will soon return to Egypt and become a 'friend of the god'. When the crowd hears the response, they begin to celebrate the priest and shower him with honours, since no one else apart from Lycurgus of Sparta had ever been declared a 'friend of the god'. ${ }^{29}$ Kalasiris is given special benefits, such as the right to live in the precinct of the god at public expense; in exchange, he must oversee the ceremonies and sacrifices that take place in the sanctuary. The best reward, however, is the possibility of meeting all the philosophers and wise men who visit the sanctuary and fill nearby streets and squares with enlightened discussions and conversations $(2,27,1-2)$. This Plutarchean prerogative of the sanctuary constitutes a sort of file rouge in Heliodorus' description of Delphi.

The exceptional nature of the response received by Kalasiris is highlighted by the irregular way in which the consultation of the oracle occurs: it is a public response, heard by all those present. In addition, Kalasiris does not offer the sacrifice normally expected from those consulting the oracle, nor does he respect the waiting list imposed on pilgrims, who usually came after the inhabitants of Delphi

\footnotetext{
${ }^{26}$ See Bommelaer - Laroche 1991, 228-230 (cf. Plut. De Pyth. 402 C) and 232-233.

${ }^{27}$ See also Paus. 10,8,9-10. The pilgrims who visited the sanctuary had to take a bath in its sacred waters before entering the temenos of Apollo to consult the oracle, as Euripides also attests (Ion. 94-96; Phoen. 220-222). Athletes too washed themselves in the Kastalia spring before taking part in the Pythian competitions.

${ }^{28}$ Weir 2004, 77-81.

${ }^{29}$ On Lycurgus' encounter with the Pythia, see Hdt. 1,65,2-3.
} 
and those entitled with the right of promanteia ${ }^{30}$ Heliodorus certainly meant this deviation from the norm to be apparent to his readers, who would have been familiar with literary antecedents dealing with Delphic consultations, starting with Euripides' Ion (225-229); this tragedy, as we shall see, represents a constant point of reference for the whole Delphic section of the novel.

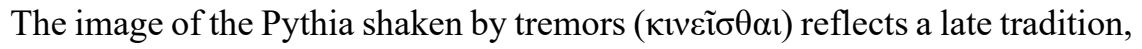
influenced by Christian writers. In Classical sources the Pythia is traditionally represented as sitting on the tripod uttering cries and songs. This is also how she is described in Euripides' Ion (91-92) and depicted on an Athenian red-figure cup found in Vulci. ${ }^{31}$ The Pythia's inspiration is described here as coming from the god alone and not from any other sources. Diodorus Siculus and Plutarch are the first authors to mention a sort of pneuma or breath released by a 'chasm' in the soil beneath the tripod, which is said to inspire her in a 'peaceful way'. ${ }^{32}$ Others say that she drinks water from the Kassotis spring which runs under the temple, or that she chews laurel leaves, ${ }^{33}$ but only Christian writers begin to talk about a 'madness' produced by the vapours coming from the chasm, which make her shake and pronounce unintelligible words. ${ }^{34}$ Although Heliodorus' novel represents a pagan response to the widespread Christian religion, we should not be surprised if some ideas - at this stage - had become ingrained in public opinion and accepted by even the most radical supporters of paganism. Nonetheless, the importance of this oracle in the novel reflects the high repute of oracles in Julian's pagan Empire, something endorsed by Heliodorus in his search for Greekness. ${ }^{35}$

As I have mentioned above, Euripides' Ion is the principal source for Heliodorus in this section. ${ }^{36}$ The similarities are noteworthy: two children, abandoned by their parents with some objects that will make the final identification possible, grow up in the sanctuary of Delphi under Apollo's protection. In both works Delphi is introduced in relation to its oracular function, because the oracles released to the protagonists have the function of resolving the action and reconciling parents and children; Xutos finds his legitimate son Ion, and Kalasiris is inspired to

${ }^{30}$ On the mode of consultation, see Scott 2014, 15-21.

${ }^{31}$ Berlin, Altesmus. F 2538 (ARV $\left.V^{2}, 1269.5\right)$. See Scott 2014, 18-30.

${ }^{32}$ Diod. 16,26; Paus. 10,5,7; Plut. De Defect. Oracul. 433c-d, 435c-d, 437c-438d; Amator. 759B. See also Strab. 9,3,5.

${ }^{33}$ Paus. 10,24,7; Luc. Bis. Accus. 1.02-28. Johann. Chrys. In epist. I ad Corinth. 61,242.

${ }^{34}$ See Johann. Chrys. In epist. I ad Corinth. 61,242, who lived in the fourth century AD and may have been a contemporary of Heliodorus. On the relationship between Christianity and paganism in the Aethiopica, see Morgan 2005.

${ }^{35}$ See Gregory 1983; Athanassiadi 1991; Digeser 2004. On the role of Apollo in the Aethiopica, see Bargheer 1999, 114-118.

36 See Clavo 2003. 
bring Charikleia back to her homeland and search for her parents. Heliodorus recalls the Athenian element, so dominant in Euripides' tragedy, through the figure of Knemon, the Athenian travel companion who accompanies Kalasiris, Theagenes and Charikleia in their peregrinations and to whom Kalasiris recounts the whole Delphic episode. ${ }^{37}$

The closest similarities, however, are between the figures of Charikleia and Kalasiris, on the one hand, and their counterpart Ion, on the other: they all live in the temenos of the god and serve him by performing ancillary duties. Kalasiris supervises the sacrifices and the ceremonies but, properly speaking, he is not a servant of the god like young Ion. The latter is a chrysophylax, favoured by Apollo, and is depicted in the act of sweeping the steps of the altar, which have been soiled by birds (102-124). Kalasiris gives the impression of having some honorary tasks that he can fulfil whenever he wishes and which leave him a lot of spare time to chat with other philosophers who visit the sanctuary. More similar to Ion is Charikleia, who from birth has been brought up by Charikles, the priest of Apollo, in the precinct of the god, like Ion. She is entitled to be the akolyte of Artemis and presides over the Pythian Games $(2,33,4)$. She is also represented as living in a house within the temenos $(3,6,1,4,6,3)$, by contrast to Ion, who sleeps anywhere in the precinct (315). Perhaps this reflects the state of the sanctuary in Roman times, when a house was built (the so-called peristyle-house) on the eastern side of the temenos's wall, in proximity of the gate, possibly as a dwelling place for the Pythia. ${ }^{38}$ However, Charikleia's special abode resembles some kind of fourth-century $\mathrm{AD}$ convent for pagan nuns, and finds no parallels in the Classical age in which the novel is set.

The role of priestess of Artemis also has no historical basis because the evidence for the worship of this goddess at Delphi is shaky. ${ }^{39} \mathrm{~A}$ cult place possibly existed in proximity of Apollo's temple and was later incorporated into the temple of Athena; ${ }^{40}$ another possibility is that the goddess was venerated in the terrace of Marmaria, where the temple of Athena Pronaia was erected, and the tholos could be connected with her cult. ${ }^{41}$ Literary and epigraphical sources, however, seem to imply a sort of joint cult of the divine twins, perhaps in imitation of the Delian couple, though on a small scale. Aristonous' paean to Pythian Apollo affirms that Artemis possesses these places with her pack of hunting dogs, ${ }^{42}$ while the short

\footnotetext{
${ }^{37}$ Knemon's story and the reasons that forced him to abandon Athens are recounted in Book 1. On the Athenian background he evokes, see Bowie 1995, 270-273.

${ }^{38}$ Bommelaer - Laroche 1991, 162-163; Weir 2004, 99-100.

${ }^{39}$ Pouilloux 1983, 268-269; Rougemont 1992.

${ }^{40}$ Scott 2014, 103.

${ }^{41}$ Bommelaer - Laroche 1991, 27, 50-51, 67-68.

42 Powell 1925, 162-164.
} 
Homeric Hymn to Artemis (27) describes the goddess reaching her brother's temple at Delphi with a chorus of Charites and Muses. A fourth-century BC inscription records an Amphictyonic oath to Apollo, Leto, and Artemis, ${ }^{43}$ and the eastern pediment of the Classical temple represented Apollo, Artemis, Leto, and the Muses. ${ }^{44}$ Some sort of cult of Artemis thus existed, but the overwhelming role assigned to her akolyte in the novel is certainly exaggerated by Heliodorus in order to emphasize the physical and moral similarities between the girl and the goddess. $^{45}$

\section{The procession and the Games: Classical Greece in the Imperial age}

The identification between Charikleia and Artemis is a recurrent theme in the novel but is particularly evident in the procession of the Enians, which constitutes a significant part of this Delphic section (2.1-5). The Enians, a Thessalian tribe, come to Delphi to honour their ancestor Neoptolemus at the time of the Pythian Games and organize a great procession that culminates with a sacrifice and a banquet. ${ }^{46}$ Their leader is Theagenes, who leads the boys' rank in all his splendour and claims to be a descendant of Achilles. At some point, also the priestess of Artemis, Charikleia, joins the parade. The description of the procession is long and detailed and Heliodorus displays his ekphrastic ability by carefully depicting the sequence of animals and attendants, and their ornate outfits - especially those of Charikleia and Theagenes. The narrative purpose of this long section is thus to present the protagonists again (after the first description provided in Book 1,2), and to underline their exceptional beauty and moral integrity, which makes them superior to all other attendants and an object of admiration by the crowd. ${ }^{47}$

Charikleia appears to the public dressed like the goddess, with a long purple tunic and a belt formed by a couple of intertwined golden snakes $(3,4,2-6) \cdot{ }^{48}$ In

${ }^{43}$ C.I.G. 1688, from Delphi.

${ }^{44}$ Paus. 10,19,4.

${ }^{45}$ See Bargheer 1999, 121-123.

${ }^{46}$ On the alleged connections between the Enians and Achilles see Pouilloux 1983. On the significance of this theoria in Imperial times see Rutherford 2013, 349-354.

47 See Hilton 1996, 195: 'Heliodorus' description of the encounter between Theagenes and Chariclea at the $\dot{\varepsilon} v \alpha \gamma ı \sigma$ ó $\varsigma$ of Neoptolemus at Delphi shows that this scene constitutes the true opening of the narrative. [...] The choice of Delphi for the location of this opening adds significantly to the symbolic subtext of the novel and considerably enhances the characterization of the hero and heroine'.

${ }^{48}$ One of the objects Ion possesses from his birth is a necklace with a snake pendant (4271429). Snakes, in fact, had a particular connection with Delphi, due to its foundation myth, 
her left hand she holds a golden arch and in her right one a torch, and she wears a quiver on her shoulder. The gaze of her eyes, which shine brighter than fire, emphasizes the divine appearance of the girl. As several scholars have shown, such an overlap between the god and the protagonist is a device often employed by novelists in order to introduce the epiphany of a deity. ${ }^{49}$ The deity - Artemis in this case - manifests himself or herself in the novel though his mortal counterpart - the heroine Charikleia, here - for religious and narrative purposes. Artemis/Selene is the female counterpart of Apollo/Helios. ${ }^{50}$ The description of the girl's appearance and outfit is filled with visual motifs which can be traced back to the figurative arts, because it evokes the ekphrasis of a cult statue. ${ }^{51}$

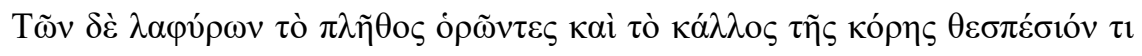

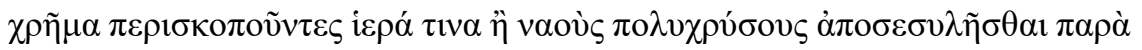

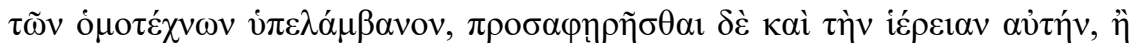

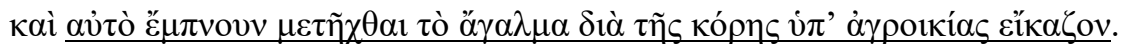

When they saw the huge quantities of booty and looked upon the girl, whose beauty seemed to exceed that of humankind, they thought that their comrades must have looted a holy place, a temple full of gold; had they carried off the priestess too, they wondered, or was the girl the statue of a goddess, a living statue? $(1,7,2)$

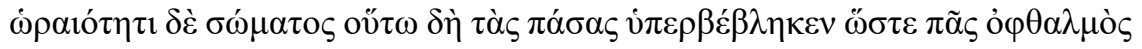

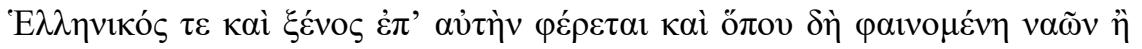

and with prophecy. Snake jewels - particularly armbands - became extremely popular from the Hellenistic age onwards.

${ }^{49}$ See Hägg 2002; Cioffi 2014. As Cioffi (2014, 33-34) writes, 'epiphanic situations, which are often mediated through the visual arts and have a strong tendency to be focalized through the perceptions and experiences of an internal audience, can serve as an alternative or supplement to ekphrasis. By shifting attention away from the object of perception to the experience of viewing, they offer the novelists one strategy for describing the indescribable.'

${ }^{50}$ See Whitmarsh 2011, 110, who underlines the oriental background of these cults. The equation between the Sun and Osiris, and between the Moon and Isis, was a standard one at this time: see Diod. Sic. 1.11.1 and Plut. De Is. et Os. 372d-e. Kalasiris was a priest of Isis at Memphis and this suggests a further connection with the identification between Charikleia and Artemis. Nonetheless, this does not mean that the novel must be understood as a mysteric text connected to the cult of Helios, as Merkelbach does (see above, n. 13).

${ }^{51}$ On Charikleia's ekphrasis in this passage, see Bartsch 1989, 120-122; Hardie 1998; Whitmarsh 2002, 116-121; Webb 2009, 184-185. 


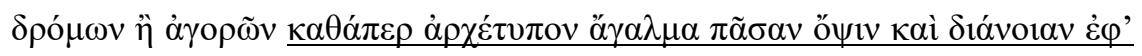

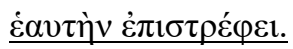

In physical beauty she is so superior to all other women that all eyes, Greek and foreign alike, turn towards her, and wherever she appears in the temples, colonnades, and squares, she is like a statue of ideal beauty that draws all eyes and hearts to itself. $(2,33,3)$.

Charikleia is compared to an agalma in several other passages of the novel, ${ }^{52}$ so that the overlap with Artemis is enacted through the cult statue, which serves as a medium between the heroine and the goddess. ${ }^{53}$ This motif accords with the interest in visual and material elements present in the previous ekphrasis of the sanctuary made by Kalasiris. ${ }^{54}$ Even in this case, the description is enriched by psychological details, since the narrator conveys the point of view of the crowd, who admires Charikleia and cannot distinguish between the $\dot{\alpha} \lambda \dot{\eta} \theta \varepsilon 1 \alpha$ of the girl's appearance and the $\delta$ ó $\xi \alpha$ of her resemblance to the goddess.

As has been extensively discussed in the scholarly literature, the heroic cult of Neoptolemus had ancient origins and must be interpreted as a sort of minor cult connected with the divine cult of Apollo. ${ }^{55}$ Such a connection is emphasized by

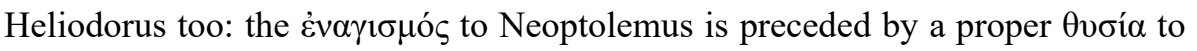
Apollo $(2,35)$, intended to propitiate the god. The antiquity of the cult is testified by Pindar, who mentions it and the related sacrifice in Nemean 7 (43-48); ${ }^{56}$ the myth of Neoptolemus is recounted, with some variants, also in Paean 6, which was possibly designed to be performed by an Aeginetan chorus at Delphi, perhaps on the occasion of the Theoxenia. ${ }^{57}$ The sacrifice and offerings to Neoptolemus were probably made on this occasion, not during the Pythian festival, as

52 See 1,7,2, 2,33,3, 10,9,3. Also in Long. 2,23,1 the nymphs who appear in Daphnis' dream 'look like tall and beautiful women, half naked and barefoot, with loose hair, similar to their own statues', and the description coincides with that of the agalmata in Long. 1.4.2. In the same way, in Charit. 1.1.1 Callirhoe is addressed as the 'agalma of the whole of Sicily' at the beginning of the novel and is often compared to Aphrodite, but when she is depicted while taking a bath $(2,2,2)$, she is said to closely resemble Praxiteles' Aphrodite of Cnidus (Hunter 2008, 759-761; see also Zeitlin 2003, 80-81).

${ }^{53}$ See also Whitmarsh 2002, 116-120.

${ }^{54}$ See above.

55 See Fontenrose 1960, 198-211; Suárez de la Torre 1997.

${ }^{56}$ See Woodbury 1979; Suárez de la Torre 1997; Loscalzo 1998; Currie 2005, 296-340.

${ }^{57}$ See Suárez de la Torre 1997; Currie 2005, 296-340. The scholia to Nem. 7.68b, 150a comment that the positive version of the myth in Nemean 7 was meant to be an apology for the negative portrayal of Neoptolemus in the Paean, but such a reconstruction is now commonly rejected (Currie 2005, 321-331). 
Heliodorus claims. Furthermore, the example of the Aeginetans shows that different communities could perform processions and sacrifices in honour of Neoptolemus, not only the Enians or the Thessalians.

The cult of Neoptolemus, whose tomb and shrine were located in the northeast area of the sanctuary, close to the temple of Apollo, was renewed after the invasion of the Gauls in 279/8 BC. ${ }^{58}$ Pausanias $(1,4,4)$ states that Neoptolemus was one of the heroes who contributed to the expulsion of the enemies from the site, and thus received new honours from the inhabitants and pilgrims. ${ }^{59}$ Furthermore, the description of his cult at Delphi is in line with the revival of hero cults and bloody sacrifices promoted by the emperor Julian in the context of his general 'paganization' and 'hellenization', and is thus consistent with Heliodorus' ideology and aim. ${ }^{60}$

We do not have a clear idea of what form the celebrations in honour of Neoptolemus took, ${ }^{61}$ so it is not easy to establish to what extent Heliodorus' description is realistic. As Rougemont has noted, it would have been difficult to stage a procession as magnificent as the one recounted by Heliodorus in the narrow space of the Via Sacra and of Apollo's precinct, given how overcrowded this area was with

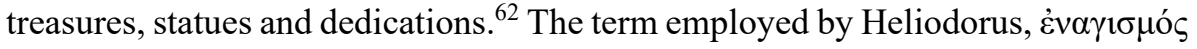
$(2,34,7,2,35,2-3)$, is the same as that employed by Pausanias $(10,24,6)$ and often applied to heroic cults, which required the full holocaust of the victim. ${ }^{63}$ Nonetheless, there is an overlap here with the $\theta v \sigma i \alpha$, since in most cases it was not the whole body of the sacrificial victim that was burnt on the pyre, but only the outermost parts ( $\alpha \kappa \rho \alpha)(3,5,2)$. The rest of the meat is consumed by the participants at the banquet organized by Theagenes and his companions $(3,6,1)$.

The general impression, however, is that the literary background to this episode is overwhelming and Heliodorus imagines a scene that carefully follows his most beloved models, Euripides and Philostratus. Euripides' Andromache (10691172), in particular, is the first and most qualified source to attest that Neoptolemus was treacherously killed by Orestes at Delphi, while he was sojourning in the sanctuary to consult the oracle ${ }^{64}$ Both in the Aethiopica and in the Andromache Neoptolemus is a positive figure, closely connected to that of his father, Achilles, and to his grandparents, Thetis and Peleus.

\footnotetext{
58 See Paus. 10,23-24; Bommelaer - Laroche 1991, 195.

${ }^{59}$ See also Fontenrose 1960, 198-211.

${ }^{60}$ See n. 12 above.

${ }^{61}$ On possible reconstructions see Fontenrose 1960, 191-211; Currie 2005, 303-307.

${ }^{62}$ Rougemont 1992, 94.

${ }^{63}$ Ekroth 2002, 74-128, 233-242.

${ }^{64}$ On the several versions of the myth, see Fontenrose 1960, 212-225.
} 
The same connections are remarked by Philostratus' Heroicus (52-53), whose description of the rites the Thessalians perform every year on Achilles' tomb represents the closest antecedent and the best source for Heliodorus' passage.$^{65}$ Here we find the same overlap between heroic and divine ritual, since the Thessalians honour Achilles 'partly as a god and partly as a hero'. The flesh of the victims is not completely burnt, but only the viscera; the rest consumed at a banquet, where the hero and his friend Patroclus are also invited $(53,13)$. Inviting a hero to attend the feast is a typical feature of Heroxenia rituals, which are also attested in the Delphic cult of Neoptolemus. ${ }^{66}$

The closest point of contact between the two passages is represented by the hymn to Thetis sung by the chorus of girls in the procession described in the $\mathrm{Ae}$ thiopica $(3,2,4):{ }^{67}$ Thetis is praised and invoked as the mother of Achilles, who generated Neoptolemus, whose benevolence and protection is now being requested. The first lines are a direct imitation of the hymn to Thetis that the Thessalians sing in the Heroicus (53.10), although here only the connection with Achilles is discussed. Furthermore, a positive image of Neoptolemus is provided by Philostratus too, who claims that he is 'noble, though inferior to his father' (Her. 52,2).

After Theagenes and Charikleia fall in love at the procession, each returns to his or her home, suffering from the pangs of passion and thinking in despair of his beloved. The next opportunity for them to meet is at the Pythian Games, since the akolyte of Artemis - according to Heliodorus' inventiveness - has the duty of assigning the victory prize to the winner in the armed race. ${ }^{68}$ When the moment of the competition arrives, the only person who wants to compete is a certain Ormenos from Arcadia, who has won all the previous competitions and instilled fear into his opponents to the point that nobody dares compete again. The judges are about to cancel the race, when Theagenes proclaims that he will compete, aiming to receive the prize from Charikleia's hands. As expected, he defeats his opponent and is crowned victor. ${ }^{69}$

${ }^{65}$ See Hilton 2012a, who also underlines the strong influence of Quintus of Smyrna as 'catalyst of the change in characterization of Neoptolemos in the Aithiopika' (64). On the connections between Heliodorus and Philostratus, see also Morgan 2009.

${ }^{66}$ Schol. Nem. 7,68a. The Heroxenia mentioned here are possibly connected to the abovementioned Theoxenia, which also included rituals in honour of Neoptolemus. See Ekroth 2002, 136-140, 177-199; Currie 2005, 303.

${ }^{67}$ See Bowie 2006, 77-81; Hilton 2003 and 2012a. Vichi Ciocani 2016 highlights parallels between the hymn to Thetis and the Homeric Hymn to Demeter.

${ }^{68}$ Heliodorus $(4,21,1)$ later remarks that the practice was abandoned after Charikleia's abduction. See n. 10 above.

${ }^{69}$ Heliod. 4,1-4. 
The description of the race and the Games is consistent with the organization of the festival in Roman times. ${ }^{70}$ The new stadium, built by Herodes Atticus at the end of the second century BC (and still visible today), with its great seating capacity, gave an impulse towards the renewal of the Games. The Pythian Games, which took place every four years, and were - even in Roman times - the second most prestigious festival after the Olympics, attracted competitors and visitors from all over the Greek and Mediterranean world, who came to take part in the competitions, consult the oracle and visit the sanctuary. ${ }^{71}$ The programme was rich and varied: the armed race was introduced in $498 \mathrm{BC}^{72}$ and was one of the most spectacular competitions, although participants in Roman times no longer competed in full hoplite armour, but in a lighter version, which only included a helmet and shield..$^{73}$ Theagenes' full armour ( $\pi \alpha v o \pi \lambda i$ i $\left., 4,3,1\right)$ is thus chronologically inconsistent, but serves to underline the contrast with his opponent's light

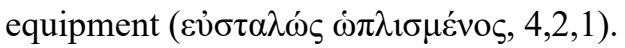

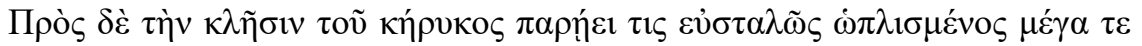

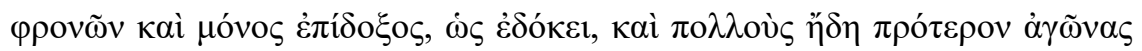

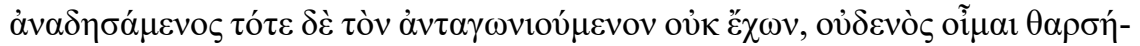

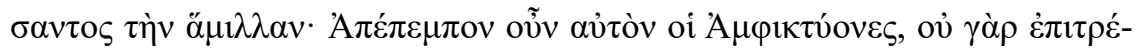

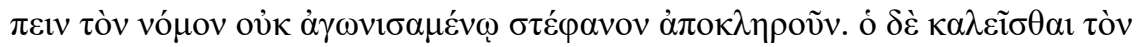

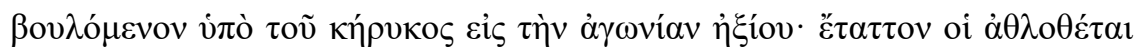

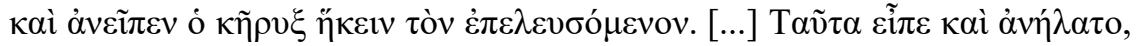

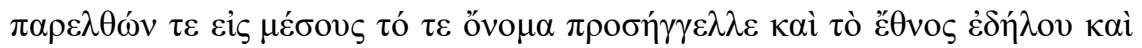

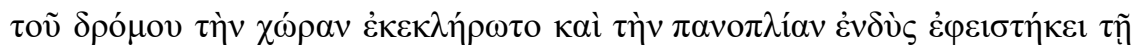

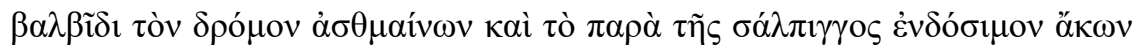

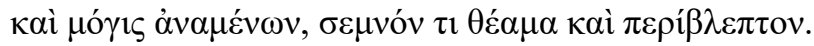

In response to the herald's summons, a man in light armour stepped forward. He clearly had a high opinion of himself and considered himself the star of the show. He had won many victories in the past, but on this occasion there was no one to oppose him; I suppose no one felt he had a chance of beating him. The Amphiktyones were on the point of dismissing him, as the rules did not allow the crown of victory to be awarded to anyone who had not taken part in a contest, but he asked that the herald should invite all comers to race

\footnotetext{
${ }^{70}$ On athletics in Roman times, see Weir 2004; Newby 2005; Remijsen 2015.

${ }^{71}$ See Weir 2004, 108-139.

${ }^{72}$ Paus. 10,7,7. Two inscriptions commemorating victories in the armed race at Delphi are 59 and 80 Moretti.

${ }^{73}$ See Gardiner 1930, 140-142; Golden 2004, 84-85.
} 
against him. The umpires gave the word, and the herald proclaimed that anyone who would contest the race should come forward. [...] With these words, he leapt to his feet and strode out into the center of the stadium, where he gave his name and stated his nationality and then drew lots for the lane in which he was to run. He donned the full set of armour and stood on the starting line, panting his eagerness for the race, so impatient that he could scarcely wait for the trumpet's starting signal, an awesome, magnificent sight. $(4,2,1-3,1)$

The two competitors are announced by the sound of the trumpet and by a herald, who declares their name and nationality, in accordance with the standard form of $\dot{\alpha} \gamma \gamma \varepsilon \lambda i \alpha ;{ }^{74}$ at the end, Theagenes is again proclaimed victor by the herald and crowned with a laurel wreath, as the Delphic custom prescribed. However, Heliodorus' statement that the judges were going to cancel the competition, because only one runner had come forth, is in contrast with the well-known practice of ákovití ('dustless') victory, obtained by an athlete without having to get his hands dirty, so to speak. ${ }^{75}$ This means that an athlete could be proclaimed victor without competing if his opponents, intimidated by his strength or track record, pulled out of the competition. ${ }^{76}$ This type of victory, attested from the Archaic to the Imperial age for any speciality, was considered particularly prestigious - as prestigious, in fact, as victories achieved $\dot{\alpha} \pi \tau \dot{\omega} \varsigma$ (i.e. without ever falling down). Athletes were proud to advertise such victories in memorial inscriptions or epinician odes. ${ }^{77}$ Akovití victories were more common for wrestlers, as Philostratus declares in his essay On Gymnastics (11), but some examples in running competitions are also attested. $^{78}$

Heliodorus' overlooking of this practice has thus raised several doubts among scholars and attempts have been made to solve the problem, ${ }^{79}$ but the easiest explanation is once again found in the literary sources that inspired Heliodorus, rather than in the material reality of his own times. Heliodorus probably relied on his favourite authors, including Philostratus. Furthermore, the whole episode of

${ }^{74}$ See Nash 1990, 11-24; Wolicki 2002; Nobili 2016b, 159-172.

${ }^{75}$ See Wachter 1995, who adduces examples from a military context, such as Thuc. 4,73,2. Others believe the term comes from the powder which athletes put on their bodies before competing (see Plin. N.H. 35,139; Ebert 1972, 54; Crowther 2001, 29-30).

${ }^{76}$ See Robert 1968, 246-249; Crowther 2001; Brunet 2010; Pleket 2014, 105-106; Nobili 2016b, 16-17, 62-63.

77 See CEG 372, 844; FGE 25; Pind. Ol. 9,93; Bacch. ep. 11,15-23.

${ }^{78}$ See for example 76 Moretti, on a winner in the dolichos at Argos in the $2^{\text {nd }}$ century BC.

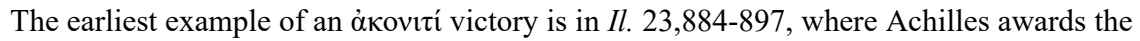
first prize in the javelin throw to Agamemnon for his reputation.

${ }^{79}$ Robert 1968, 246-249; Pouilloux 1983. 
the competition serves to draw attention to the figure of Theagenes, who exhibits his athletic prowess by surpassing an apparently invincible opponent. An ỏKovıí victory would have made such a reconstruction impossible.

\section{Conclusions}

Heliodorus' reconstruction of the material aspects of the sanctuary of Delphi in the Imperial age, with specific attention to the ritual aspects connected with the oracle and to the Pythian festival, is based mainly on literary sources, although first-hand knowledge cannot be excluded. Authors of the Classical era, such as Euripides and Pindar, are fruitfully drawn upon, alongside authors closer to Heliodorus' age, such as Plutarch and Philostratus, in the context of a precise and coherent ideological programme: a revival of Classical and pagan Greekness, as promoted by the Emperor Julian's reforms. The result is a lively description of the sanctuary and its rites, which fluctuates between the fourth century BC (the dramatic age of the novel) and Heliodorus' age (the fourth century AD). Although some details are included for narrative reasons, the general overview fits the image of the sanctuary given by the sources, with its crowded assemblies of pilgrims, enthusiastic acclamations of successful athletes and the communal feeling of being in a special place, the navel of the world, visited by the gods and admired by humans. ${ }^{80}$

\section{Bibliography}

Athanassiadi, P. 1991. 'The Fate of Oracles in Late Antiquity: Didyma and Delphi', Deltion tes Christianikes Archaiologikes Hetaireias 15, 271-278.

Bargheer, R. 1999. Die Gottesvorstellung Heliodors in den Aithiopika, Frankfurt am Main: Peter Lang.

Bartsch, S. 1989. Decoding the Ancient Novel. The Reader and the Role of Description in Heliodorus and Achilles Tatius, Princeton: Princeton University Press.

Beck, R. 1996. Mystery Religions, Aretalogy and the Ancient Novel, in: G. Schmeling (ed.), The Novel in the Ancient World, Leiden: Brill, 131-150.

Bommelaer, J.F. - Laroche, D. 1991. Guide de Delphes. Le site, Athènes: Ecole Française d'Athènes.

Bowersock, G.W. 1994. Fiction as History. Nero to Julian, Berkeley - Los Angeles.

Bowie, E. 1995. 'Names and a Gem. Aspects of Allusion in Heliodorus' Aethiopica', in: D. Innes, H. Hine, C. Pelling (eds.), Ethics and Rhetoric. Classical Essays for Donald Russell on his Seventy-Fifth Birthday, Oxford - New York: Claredon Press, 269-280.

${ }^{80}$ I wish to thank the anonymous referees for the useful suggestions and comments. 
Bowie, E. 2006. 'Viewing and Listening on the Novelist's Page', in: S.N. Bryne, E.P. Cueva, J. Alvares (eds.), Authors, Authority, and Interpreters in the Ancient Novel. Essays in Honor of Gareth L. Schmeling, Groningen: University of Groningen Press, 60-82.

Bradbury, S. 1995. 'Julian's Pagan Revival and the Decline of Blood Sacrifice', Phoenix 49, 331-356

Brunet, S. 2010. 'Winning the Olympics Without Taking a Fall, Getting Caught in a Waistlock, or Sitting out a Round', ZPE 172, 115-124.

Cioffi, R.L. 2014. 'Seeing Gods: Epiphany and Narrative in the Greek Novels', AncNarr 11, 142.

Clavo, M.T. 2003. 'Comunicare a Delfi: lo Ione euripideo e le Etiopiche di Eliodoro', in: M. Guglielmo, E. Bona (eds.), Forme di comunicazione nel mondo antico e metamorfosi del mito: dal teatro al romanzo, Alessandria: Edizioni dell'Orso, 299-321.

Crowther, N.B. 2001. 'Victories without Competition in the Greek Games', Nikephoros 14, 2944 (reprinted in N.B. Crowther, Athletika. Studies on the Olympic Games and Greek Athletics, Hildesheim: Weidmann 2004, 281-295).

Currie, B. 2005. Pindar and the Cult of Heroes, Oxford: Oxford University Press.

De Jong, I.J.F. 2012 (ed.). Space in Ancient Greek Literature. Studies in Ancient Greek Narrative, Leiden: Brill.

Digeser, E.D. 2004. 'An oracle of Apollo at Daphne and the Great Persecution.' CPh 99, 5777.

Dillon, M. 1997. Pilgrims and Pilgrimages in Ancient Greece. London \& New York: Routledge.

Dowden, K. 2005 'Greek Novel and the Ritual of Life: an Exercise in Taxonomy', in: S. Harrison, M. Paschalis, S. Frangoulidis, Metaphor and the Ancient Novel. Eelde: Barkhuis, 23-35.

Dowden, K. 2010. 'The Gods in the Greek Novel', in: N. Bremmer, A. Erskine (eds.), The Gods of Ancient Greece: Identities and Transformations, Edinburgh: Edinburg University Press, 362-374.

Ebert, J. 1972. Griechische Epigramme auf Sieger an gymnischen und hippischen Agonen, Berlin: Akademie.

Edsall, M. 2002. 'Religious Narratives and Religious Themes in the Novels of Achilles Tatius and Heliodorus', AncNarr 1, 114-133.

Ekroth, G. 2002. The Sacrificial Rituals of Greek Hero-Cults, Liège: Centre international d'Etude de la religion grecque antique.

Elemer, D.F. 2008. 'Heliodoros' Sources: Intertexuality, Paternity, and the Nile', TAPA 138, 411-450.

Elsner, J. 2002. 'Introduction: the Genre of Eckphrasis', Ramus 31, 1-18.

Fontenrose, J. 1960. 'The Cult and Myth of Pyrrhos at Delphi', UCPCA 4, 191-266.

Galli, M. 2005, 'Pilgrimage as Elite Habitus: Educated Pilgrims in Sacred Landscape During the Second Sophistic', in: J. Elsner, I. Rutherford (eds.), Pilgrimage in Graeco-Roman \& Early Christian Antiquity. Seeing the Gods, Oxford: Oxford University Press.

Gardiner, E.N. 1930. Athletics of the Ancient World, Oxford: Oxford University Press.

Golden, M. 2004. Sport in the Ancient World from A to Z, London: Routledge.

Goldhill, S. 1994. 'The Naive and Knowing Eye: Ecphrasis and the Culture of Viewing in the Hellenistic World', in: S. Goldhill, R. Osborne (eds.), Art and Text in Ancient Greek Culture, Cambridge: Cambridge University Press, 197-223.

Goldhill, S. 2007. 'What is Ekphrasis for?', CP 102, 1-19.

Gregory, T.E. 1983. 'Julian and the Last Oracle at Delphi.' GRBS 24, 355-366. 
Hägg, T. 2002. 'Epiphany in the Greek Novels: The Emplotment of a Metaphor', Eranos 100, 51-61 (reprinted in T. Hägg, Parthenope: Selected Studies in Ancient Greek Fiction, Copenhagen: Museum Tusculanum Press 2004, 141-155).

Hardie, P. 1998. 'A Reading of Heliodorus, Aithiopika 3.4.1-3.5.2', in: R. Hunter (ed.), Studies in Heliodorus, Cambridge: The Cambridge Philological Society, 19-39.

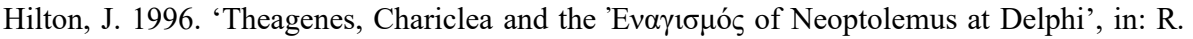
Faber, B. Seidensticker (eds.), Worte, Bilder, Töne. Studien zur Antike und Antikerezeption. Bernhard Kytzler zu ehren, Würzburg: Königshausen \& Neumann, 187-196.

Hilton, J. 2003. 'Heliodorus the Poet', in: A.F. Basson, W.J. Dominik (eds.), Literature, Art, History: Studies on Classical Antiquity and Tradition, Bern: Peter Lang, 235-248.

Hilton, J. 2012a. 'The Cult of Neoptolemos at Delphi in Heliodoros' Aithiopika', AClass 55, 57-68.

Hilton, J. 2012b. 'The Sphragis of Heliodoros, genealogy in the Aithiopika, and Julian's Hymn to King Helios', Ágora, 14, 195-219.

Hunter, R. 2008. 'History and Historicity in the Romance of Chariton', in: Id., On Coming After, Part 2: Comedy and Performance, Greek Poetry of the Roman Empire, the Ancient Novel, Berlin - New York: Walter De Gruyter, 737-774.

Jones, C.P. 2010. New Heroes in Antiquity: from Achilles to Antinoos, Cambridge, Mass. \& London: Harvard University Press.

Kerényi, K. 1927. Die griechisch-orientalische Romanliteratur in religionsgeschichtlicher Beleuchtung. Darmstadt: Mohr.

Lateiner, D. 1997. 'Abduction Marriage in Heliodorus' Aethiopica', GRBS 38, 409-439.

Loscalzo, D. 1998. 'Neottolemo Boathoos a Delfi', QS 24, 119-131.

Mecella, L. 2014. 'L'enigmatica figura di Eliodoro e la datazione delle Etiopiche, «MedAnt» 17, 633-660.

Merkelbach, R. 1962. Roman und Mysterium in der Antike, München: Beck.

Moretti, L. 1953. Iscrizioni agonistiche greche, Roma: Signorelli Editore.

Morgan, J.R. 1982. 'History, Romance, and Realism in the Aithiopika of Heliodoros', Class Ant $1,221-265$.

Morgan, J.R. 1996. 'Heliodoros', in: G. Schmeling (ed.), The Novel in the Ancient World, Leiden: Brill, 417-456.

Morgan, J.R. 2005. 'Le blanc et le noir: perspectives paiennes et perspectives chrétiennes sur l' Ethiopie d' Héliodore', in: B. Pouderon and D.Crismani (eds.), Lieux, décors et paysages de l'ancien roman des origines à Byzance, Lyon: Maison de l'Orient et de la Méditerranée Jean Pouilloux, 309-318.

Morgan, J. R. 2009. 'The Emesan Connection: Philostratus and Heliodorus', in: C. Demoen and D. Praet (eds.), Theios Sophistes: Essays on Philostratus' Vita Apollonii, Leiden: Brill, 263-281.

Morgan, J.R. 2014. 'Heliodorus the Hellene. Defining Greek Narrative', in: D. Cairns, R. Scodel (eds.), Defining Greek Narrative, Edinburgh: Edinburgh University Press, 260-276.

Nash, L.L. 1990. The Aggelia in Pindar, New York: Garland.

Newby, Z. 2005. Greek Athletics in the Roman World: Victory and Virtue. Oxford Studies in Ancient Culture and Representation. Oxford: Oxford University Press.

Nobili, C. 2016a. 'Mercanti e cortigiane. La fortuna di un topos da Saffo a Eliodoro', RFIC $144,5-24$.

Nobili, C. 2016b. Corone di gloria. Epigrammi agonistici ed epinici dal VII al IV secolo a.C., Alessandria: Edizioni dell'Orso.

Parke, H.W. 1978. 'Castalia'. BCH 102, 199-219. 
Paschalis, M. - Frangoulidis, S.A. 2002. Space in the Ancient Novel, Groningen: Barkhuis Publishing.

Pleket, H.W. 2014. 'Inscriptions as Evidence for Greek Sport', in: P. Christesen - D.G. Kyle (eds.), A Companion to Sport and Spectacle in Greek and Roman Antiquity, Chichester: Wiley Blackwell, 98-111.

Pouilloux, J. 1967. 'Une famille de sophistes thessaliens à Delphes au IIe s. ap. J.-C.', REG 80, 379-384.

Pouilloux, J. 1983. 'Delphes dans les Éthiopiques d'Héliodore', JS, 259-286.

Pouilloux, J. 1984. 'Roman grec et réalité. Un épisode delphique des Éthiopiques d'Héliodore', in: H. Walter (ed.), Hommages à Lucien Lerat, Paris: Les Belles Lettres, 691-703.

Powell, I.U. 1925. Collectanea Alexandrina. Reliquiae minores poetarum graecorum aetatis Ptolemaicae (323-146 a. C.). Oxford: Clarendon Press.

Quinn, J. 2017. In Search of the Phoenicians, Princeton - Oxford: Princeton University Press.

Remijsen, S. 2015. The End of Greek Athletics in Late Antiquity, Cambridge: Cambridge University Press.

Robert, L. 1968. 'Les épigrammes satiriques des Lucillius sur les athlètes. Parodie et réalité', in: L'épigramme grecque, Vandœuvres-Genève: Fondation Hardt, 181-295.

Rougemont, G. 1992. 'Delphes chez Héliodore', in: M.F. Baslez, P. Hoffmann, M. Trédé (eds.), Le monde du Roman grec. Actes du colloque international tenu a l'École normale supérieure (Paris 17-19 décembre 1987), Paris: Presses de l'Ecole normale superieure, 93-100.

Ross, A.J. 'Syene as face of battle: Heliodorus and late antique historiography', AncNarr 12, $1-26$.

Rutherford, I. 2013. State Pilgrims and Sacred Observers in Ancient Greece. A Study of Theōria and Theōrōi, Cambridge: Cambridge University Press.

Scott, M. 2014. Delphi: a History of the Center of the Ancient World, Princeton - Oxford: Princeton University Press.

Smith, R. 1995. Julian's Gods: Religion and Philosophy in the Thought and Action of Julian the Apostate. London \& New York: Routledge.

Squire, M. 2009, Image and Text in Graeco-Roman Antiquity. Cambridge: Cambridge University Press.

Suárez de la Torre, E. 1997. 'Neoptolemos at Delphi', Kernos 10, 153-176.

Tagliabue, A. 2013. 'Thrason's Work in the Ephesian Artemision: an Artistic inspiration for Xenophon of Ephesus' Ephesiaca', Hermes 141, 363-377.

Tagliabue A. 2015. 'Heliodorus' Aethiopica and the Odyssean Mnesterophonia: an Intermedial Reading', TAPA 145, 445-468.

Telò, M. 2011. 'The Eagle's Gaze in the Opening of Heliodorus' Aethiopica', AJPh 132, 581613.

Vichi Ciocani, E. 2016. 'Searching for a Foil to Charicleia: Heliodorus' Aethiopica and the Homeric Hymns to Demeter', Mnemosyne 69, 1-17.

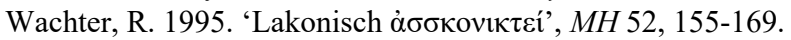

Webb, R. 2009. Ekphrasis, Imagination and Persuasion in Ancient Rhetorical Theory and Practice. Farnham - Burlington: Ashgate.

Weir, R.G.A. 2004. Roman Delphi and its Pythian Games, Oxford: Oxford University Press.

Whitmarsh, T. 1998. 'The Birth of a Prodigy: Heliodorus and the Genealogy of Hellenism', in: R. Hunter (ed.), Studies in Heliodorus, Cambridge: The Cambridge Philological Society, 93-125.

Whitmarsh, T. 2002. 'Written on the Body: Ekphrasis, Perception and Deception in Heliodorus' Aethiopica', Ramus 31, 111-125. 
Whitmarsh, T. 2011. Narrative and Identity in the Ancient Greek Novel: Returning Romance, Cambridge: Cambridge University Press.

Wolicki, A. 2002. 'The Heralds and the Games in Archaic and Classical Greece', Nikephoros 15, 69-97.

Woodbury, L. 1979. 'Neoptolemus at Delphi. Pindar, Nem. 7.30 ff.', Phoenix 33, 95-133.

Zeitlin, F. 2003. 'Living Portraits and Sculpted Bodies in Chariton's Theater of Romance', in: S. Panayotakis, M. Zimmerman, W. Keulen (eds.), The Ancient Novel and Beyond, Leiden - Boston: Brill, 71-83.

Zeitlin, F. 2008, 'Religion', in: T. Whitmarsh (ed.), The Cambridge Companion to the Greek and Roman Novel, Cambridge: Cambridge University Press, 91-108. 